\title{
Coaching To What End? The Development and Enactment of a Shared Critically Oriented Coaching Discourse
}

\author{
Laura M. Lang \\ Wisconsin, USA
}

\begin{abstract}
To what end do coaches carry out their work within schools? Literacy and instructional coaches are positioned as leaders within their schools and districts. In these leadership roles, the purposes and intended outcomes of coaching are often assumed. Using data collected during an 18-month qualitative study of four high school literacy coaches, along with critical theories of leadership and literacy, the author/participant researcher traces the development of the coaches' shared discourse and considers what could be possible if coaches considered themselves critically oriented leaders. Finally, a framework for critically oriented coaching is briefly introduced in the context of this data.
\end{abstract}

Keywords: instructional coaching, critical theory, instructional reform, coaching beliefs

As a current instructor within a university-based online coaching certificate program, I have the opportunity to interact with school-based coaches from all over the world. Coaches from Brazil, the United States, Colombia, and many other countries often reveal tensions between the instructional reforms they are asked to support and the work they believe should be prioritized. Instructional coaches are typically hired to improve student learning, either within a single school or in multiple schools. In these varied contexts, instructional reforms assume multiple forms, and they can be propelled by national or state policies, by school leadership, or by the teachers themselves. They can take the form of a prescriptive literacy or math curriculum, of mission-driven learning goals within a school, or of needs identified by individual teachers.

As each new cohort of instructional coaches advances through our certificate program, the following becomes more evident: the "why" of coaching, while it appears self-evident, is imbued with tacit beliefs about learning, teachers, students and school reform. Elliot, an instructional coach currently working in Colombia, was trained to support the implementation of a new literacy curriculum in his international school. Though he supports this curriculum, he struggles to reconcile a curriculum-focused model of coaching

This is an Open Access article distributed under the terms of the Creative Commons Attribution (CC BY) License which permits use, distribution and reproduction in any medium, provided the original work is properly cited. 
with his own preference for inquiry-based and student-centered models of coaching (e.g. Costa \& Garmston, 2002; Sweeney, 2011; Aguilar, 2013). He explained, "I can't sculpt this [teacher] into a mini-me of what I think teaching should look like." Like many coaches who encounter these tensions (Rogers, 2014), Elliot is grappling with a question that is fundamental to the coaching role: To what end am I coaching?

In my current role as a university-based educator, I encourage others to wrestle with this question through a combination of readings, discussion prompts and application activities. During the six years I spent working as a high school literacy coach, I wrestled with this question daily as I sought to reconcile my beliefs about equity-driven reform with the reforms I was asked to help teachers enact. This article presents data from an 18-month qualitative case study that I conducted with four high school literacy coaches in the Lake City School District. I was one of the four literacy coaches. At that time, my concurrent role as a doctoral student provided an opportunity for me to study our interactions and explore "To what end" we understood and enacted our coaching roles. This article traces the development of our shared discourse about instructional reform and literacy instruction, a discourse that reflected critical theories about leadership and literacy. Ultimately, a framework for critically oriented coaching is briefly introduced to catalogue how we enacted those beliefs in our coaching practice.

\section{Coaches as instructional leaders...to what end?}

Michael Apple $(2000,2018)$ reminds us that schools have historically been, and will continue to be, sites of struggle over fundamental democratic processes, what counts as knowledge and whose knowledge is privileged. Instructional reforms, though they differ in focus and scope, are manifestations of the struggle Apple describes, as they embody specific priorities about what kinds of learning should be privileged and where resources should be allocated. Embedded within these reforms are theoretical assumptions about the purpose of reform and about the purposes and intended outcomes of teaching and learning (Capper, 1998; Sirotnik \& Oakes, 1986; Apple, 2006).

As instructional leaders, literacy coaches are positioned at the center of this struggle, as they are charged with helping to improve literacy instruction within a school building. In this capacity, they are expected to support and promote instructional reform (Neufeld \& Roper, 2003; Sturtevant, 2003; IRA, 2006; Carnegie Council for the Advancement of Adolescent Literacy, 2010; Fullan, 2010). However, because their formal job descriptions are sometimes 
non-existent, insufficient or evolving, their roles can be undefined and/or ambiguous (Blamey, Meyer \& Walpole, 2008; Mraz, Algozzine \& Watson, 2008). Subsequently, they must often negotiate the "To what end?" of their work while interacting with teachers and administrators. Within schools struggling to meet the needs of a diverse student body, conversations about the intended outcome of coaches' efforts are even more crucial. Below, I share the context that allowed Lake City School District coaches to explore the "Why" and "To what end" of their work.

\section{The Coaching and Research Context}

The Lake City School District (LCSD) is a midsize urban district within the Midwestern United States. Lake City residents have access to a world-class university system, cutting-edge technology firms and multiple high-demand industry jobs. However, LCSD data also reveals stark and persistent academic achievement gaps defined by socioeconomic status and race.

At the time of this study, LCSD high schools served approximately 7,550 students in grades 9-12, and the student population reflected a diverse range of socioeconomic, ethnic, racial and religious backgrounds. Approximately 55\% of students identified as White, 23\% Black, 12\% Hispanic, 10\% Asian and 1\% American Indian. $42 \%$ of students enrolled in the district were identified as economically disadvantaged. During the same year, only $48 \%$ of students identified as economically disadvantaged scored proficient or advanced on the state's reading assessment. Similarly, while $89 \%$ of White $10^{\text {th }}$ graders scored either proficient or advanced, only $49 \%$ of Black students and $53 \%$ of Hispanic students scored proficient or higher.

The LCSD coaches were cognizant of these stark achievement gaps and understood that we had been hired to help teachers improve the literacy achievement of all students.

\section{The Participants}

Rachel, Sharon, Carol and I were all the first titled literacy coaches within the Lake City School District. When this study began, we had been working together for approximately one year. Our positions were funded through a federal grant designed to help LCSD address the academic inequities detailed above. We did not know each other prior to entering these positions, and we were each assigned to coach in one of LCSD's four comprehensive high schools. However, we soon entered a fledgling community of practice (Wenger 
et al., 2002) that would sustain, challenge and influence our work. This community of practice, the Literacy Coach Collaborative (LCC), will be described in more detail below.

All participants provided signed consent to participate in this study, including district staff members who attended some of our LCC meetings. Due to a recent shift in district priorities and role titles, Carol, Rachel and Sharon no longer work as titled literacy coaches; however, some are still employed in the district. Consequently, I have taken additional precautions to protect their identities. All names of places and participants except mine have been assigned pseudonyms. In addition, details about Carol, Sharon and Rachel are shared below in aggregate.

Prior to entering their high school coaching positions in the fall of 2008, my three colleagues had worked as a secondary English teacher, a middle school English as a Second Language teacher, and a Special Education teacher. Two of the three had Reading Specialist or Reading Teacher certifications; one did not. I entered the coaching role with ten years of experience teaching English Language Arts and reading in both urban and suburban high schools, and I was certified as a Reading Specialist. In addition, I was the only one who had formal literacy coaching experience prior to our work in LCSD. We all identify as white females; in different capacities, we had all worked to support students who had been marginalized within the school setting.

\section{Research Methods}

During the 18-month study, I interviewed each coach three times using a semi-structured protocol. In addition, Literacy Coach Collaborative meetings were audiotaped and transcribed. On two occasions, a district staff member asked me to pause the audio recorder when particularly sensitive information was being discussed. The resulting transcripts of these meetings, in addition to participant interview transcripts and retrospective field notes, were analyzed using both inductive and deductive coding methods (Saldaña, 2009). Also included in the data set were district-generated public documents related to instructional reforms discussed by the coaches.

\section{Researcher's Role}

As a participant researcher, I was acutely aware that "Neither the insider nor the outsider is gifted with immaculate perceptions" (Erickson, in CochranSmith \& Lytle, 1993, p. ix). In addition to maintaining detailed retrospective 
field notes, I also generated notes about my experiences as a participant researcher. I reflected on how I was representing others' experiences, paying particular attention, as Zeni recommends, to how each participant defined issues I assumed to be significant or problematic (2001, p. xvii). Finally, I conducted frequent member checks with my participants, giving them opportunities to confirm, clarify or question my findings.

\section{Cultivating a shared discourse}

\section{The Literacy Coach Collaborative}

While we worked in separate high school buildings, Rachel, Carol, Sharon and I met biweekly, either with district staff or by ourselves, to plan together, learn together and address specific challenges that we were each facing. The Literacy Coach Collaborative meetings took on various shapes and sizes as our work progressed and as our relationship with the LCSD districtlevel staff evolved. We met in each other's schools, the district administration building, or centrally located coffee shops. The focus of each meeting varied, depending on who was in attendance and what school or district-related initiative was prioritized at the time.

In addition to sharing insights and solving problems together, we developed tools - such as job descriptions and literacy guides - that required us to enter into negotiations around the language choices that would best reflect our beliefs. It is important to note that we were not always in agreement regarding precisely what reading and writing skills should be prioritized as we worked to design professional development opportunities within our own buildings. As mentioned previously, we entered into our coaching position with different professional experiences in education. However, the creation of shared coaching tools and resources gave us opportunities to develop and name those core beliefs about our work. Table 1 categorizes the kinds of work that we engaged in during these biweekly meetings. 


\begin{tabular}{|l|l|}
\hline $\begin{array}{l}\text { Technical } \\
\text { Work }\end{array}$ & $\begin{array}{l}\text { Share resources; Learn more about district initiatives and } \\
\text { resources; Generate ideas for solving coaching-related } \\
\text { challenges in our building; Design professional } \\
\text { development opportunities }\end{array}$ \\
\hline $\begin{array}{l}\text { Professional } \\
\text { Identity Work }\end{array}$ & $\begin{array}{l}\text { Define the coaching role; Craft common definitions of } \\
\text { terms (i.e. literacy); Define ideal relationship with our } \\
\text { administrators and district staff; Discuss and articulate our } \\
\text { role in relation to change }\end{array}$ \\
\hline $\begin{array}{l}\text { Instructional } \\
\text { Reform Work }\end{array}$ & $\begin{array}{l}\text { Articulate core beliefs about reform; Develop shared list of } \\
\text { best-practice literacy strategies; Strategize about enactment } \\
\text { and critique of instructional reform; Negotiate with district } \\
\text { staff }\end{array}$ \\
\hline
\end{tabular}

Table 1: Types of work carried out during Literacy Coach Collaborative meetings

During the LCC meetings, we engaged in sensemaking (Weick, 2001) around our coaching practice, our professional identities and our relationship to instructional reform. Rachel explained the role that the Literacy Coach Collaborative played for her.

\footnotetext{
I can't even begin to describe the sense of relief and community that the LCC has provided. I don't know if I'd still be in this position if I didn't have you guys to depend on. Being in the same boat and having your expertise and your support to rely on. And also an occasional pat on the back.
}

Because no formal coaching model was being utilized within the district at the time, the LCC meetings provided us with opportunities to discuss, compare and negotiate our beliefs with each other and with district-level staff who were present. The LCSD literacy coaches' community of practice, and the shared discourse (Bakhtin, 1984; Gee, 2011) that resulted, was constructed collaboratively by the four coaches as we engaged with the challenges we faced within our new roles and as we responded to various district requests and opportunities.

\section{Theories about language-in-use}

A focus on the coaches' shared discourse is predicated on the assumption that language is always political and that it has the power to both reify and transform existing hegemonic norms within an institution (Fairclough, 1989; Janks, 2010; Gee, 2011). Gee explains that "language simultaneously reflects contexts (what's out there in the world) and constructs (construes) it to be a 
certain way" (2011, p. 101, orig. italics). From this perspective, the language the coaches were appropriating and, ultimately, articulating publicly, allowed us to construct alternatives to the systems, approaches and beliefs that had contributed to our district's racial and socioeconomic achievement gap.

Subsequently, analyzing the discursive moves within one conversation between the four coaches can provide a window into the negotiation and development of these shared beliefs.

\section{Co-construction of a public document}

One vivid example of the development of the coaches' shared discourse could be seen when we collaborated around an upcoming presentation. During our first year of working together, Sharon, Carol, Rachel and I were asked to present to a neighboring local educational agency (LEA) about our coaching work; that LEA had just begun supporting coaches within its area schools. In preparation for our presentation, we decided to record, and ultimately share, the core beliefs about literacy that guided our work. Over breakfast at a local coffee shop, we co-constructed this document.

The excerpt below offers a window into this conversation. At the time, I was sitting in front of my laptop computer, recording what the others said and offering input. Short (.) and longer (..) pauses are noted, as are overlapping statements $(=)$; these signal moments during the conversation when we were thinking about how to formulate our thoughts and building upon each other's ideas.

Rachel: Don't type this...culturally relevant personal literacies as a bridge to - I don't know how to say this - as a bridge to (.) um (.) I don't know how to say it, as a bridge to (..)

Carol: What's the word? Power? Or to enable or to create and foster an environment for learning? Or to (..)

Laura: How about, "We strive to incorporate culturally relevant materials to master a love of" (.) because the purpose of using those materials is to get kids interested and engaged.

In the above excerpt, notice how Rachel thinks out loud, articulating her belief in "culturally relevant personal literacies." She gets stuck, however, when she tries to articulate the ultimate outcome for students. Carol jumps in, offering some possibilities. However, she frames these as questions; in doing so, she invites others to share their insights. I pick up on Carol's bid and summarize what has already been said. Next, I offer a suggested outcome, 
articulating a purpose for giving students access to culturally relevant materials. The conversation continues, offering an example of how we negotiated our beliefs around best practice literacy instruction and how we built a cohesive, collaborative statement about the student-centered goals of our work.

Rachel: Mmmm, hmmm. It's a bridge.

Carol: I just think that 'love' is, for lack of a better word, too aesthetic.

Laura: Should we say, "We strive to use culturally relevant materials to empower students to be active participants (..)

Carol: Active learners? To learn actively? To learn and think (..) What would you say, [Sharon]?

Laura: So right now, we have, "we strive to use culturally relevant materials to empower students to.." And we can always rewrite this (..)

Sharon: To interact with texts. Or, to (..) $=$

Rachel: $\quad=$ To interact with texts

Laura: To have meaningful interactions?

Rachel: With texts both on a personal and academic level? Or use personal as a bridge to academic $=$

Carol: $\quad=$ Which is our main connection to building background knowledge and all of our really best practice literacy strategies.

As the above transcript reveals, our beliefs were not fixed; they were fluid and negotiated by the group as a whole. There were explicit efforts made to ensure that each coach's voice was represented. Noticing that Sharon was characteristically quiet, Carol invited her contribution. As note taker, I frequently restated the language we had agreed upon, and clarified ("we can always rewrite this") that there was still room for revision.

Ultimately, this activity allowed us to construct and formalize our priorities as we engaged with both district and building staff; these priorities reflect the coaches' shared internally persuasive discourse (Bakhtin, 1984). Bakhtin's theory of discourse derives from the belief that language is socially constructed and that it develops in a dialogic relationship between speaker, history, perceived audience and ideology. He goes so far as to assert, "the ideological becoming of a human being, in this view, is the process of selectively assimilating the words of others" (1984, p. 340). In contrast to an 
authoritative discourse, which is "encountered with its authority already fused to it" (p. 342), the internally persuasive discourse is "half-ours and halfsomeone else's" (p. 345) It is open to be developed by the speaker, to be creatively applied to new situations. This process is evident above in the coconstructed utterances, overlaps, and questions that are posed by the coaches. Furthermore, we understood that each coach's commitment to supporting marginalized students permeated the words being shared and assimilated. Within the Lake City School District, which was struggling to meet the needs of its diverse study body, this was instrumental in allowing us to articulate our beliefs.

Our shared discourse was rooted in the belief that the status quo was insufficient. Carol expressed this during our last interview together: "I think what needs to happen in our system is HUGE. It can't just be pockets of things happening here and here and here." The fact that so many of our students of color, our English language learners and our students from lower socioeconomic backgrounds, were continuing to struggle compelled our attempts to bring about change.

A closer analysis of this excerpt, as well as many other conversations that occurred within the Literacy Coach Collaborative meetings, also reveals that the coaches prioritized beliefs and instructional activities consistent with a critical literacy stance. We believed that instruction should be built around "culturally relevant materials" that served to "empower" students to interact with texts on both "personal and academic" levels. Critical theories about literacy are described below, and an extended analysis of the coaches' shared beliefs follows.

\section{Critical theories about literacy instruction}

Critical literacy scholars argue that while texts often reflect and seek to maintain the dominant power structures, the pliable nature of language means that those texts can be "rewritten" in order to shift the existing power dynamics in favor of groups that have been disadvantaged (Morgan, 1997; Freire, 2000; Janks, 2010).

From this perspective, literacy coaches would engage with "various social, ideological, cultural and political contexts" when negotiating decisions about best practice literacy instruction and policy (Morrell, 2008, p. 5). In addition, educators working within a critical literacy framework would seek authentic instructional experiences that are driven by their students; they would 
eschew prepackaged curriculum and programs that require a one-size-fits all approach to instruction (Vasquez, 2001). Opportunities for students to read and write their "selves" (Morgan, 1997) would be prioritized, in part by valuing the resources, concerns and interests that students and their families bring into the classroom (Compton-Lily, 2004; Ladson-Billings, 2009).

\section{Critical literacy and the coaches' shared discourse}

During my last interview with Rachel, she referenced an "assumed knowledge base that we all [the lit coaches] have," one that existed as the foundation of our conversations. She not only acknowledged that shared knowledge base, but she offered a detailed description of it. Our shared discourse, Rachel contended, was comprised of "things we take for granted, like motivation, engagement and student choice and appropriate materials, welltrained teachers and resources"; these elements were presumed to be essential components of any secondary literacy program.

A review of the larger data set revealed that this "assumed knowledge base" reflected the principles of critical literacy articulated above. First, in order for literacy instruction to be engaging, culturally relevant and empowering, it must serve as a bridge between students' personal literacies and the academic literacies with which they are expected to engage at school. Students must have opportunities to have meaningful interactions with texts. Second, while providing students with choice is essential to increasing engagement, choice must be accompanied by appropriate skill instruction. As Carol stated during our final interview, "You can't just do silent reading time without doing some explicit skill instruction...".

Third, the coaches agreed that adolescents who have been identified as "struggling readers" deserve a range of intervention options taught by the most qualified reading teachers. During a LCC meeting, Rachel communicated this passionately, and Carol concurred.

\footnotetext{
Rachel: And they need one-on-one instruction by a LITERACY SPECIALIST. But that is something we need to work on. I don't know if it's getting a rant or whatever it is. We've got to have it. We've got to have it! And I feel very, very strongly about it.

Carol: I'm with you!

Rachel: And I'm going to continue to march down this line because we will not be able to help these kids unless we have something like that.
} 
Here, Rachel urges the coaches to advocate for the hiring of qualified literacy teachers ("something we need to work on"), by either yelling about it ("getting a rant") or using another tactic. Like so many districts, LCSD had historically supported reading instruction in the high schools primarily by funding the purchase of commercial reading curricula in lieu of hiring expert reading teachers or providing additional training in reading instruction. To us, this meant that our struggling readers, a disproportionate number of whom were students of color, were not getting the support that they deserved. No "one-sizefits-all" program was going to meet the needs of our diverse student body.

\section{The Power of a Shared Discourse: It Gives Us "Muscle"}

The beliefs articulated above both constructed and were constantly refined by the shared discourse that the coaches shaped collaboratively. This discourse, and the meetings in which it was developed, "gave us muscle" (Carol) as we interacted with our building staff. It also allowed us to jointly advocate for change that would support the needs of students who had been traditionally marginalized within our district.

Wenger, McDermott \& Snyder (2002) explain why shared understandings are important within the context of a community: "One of the primary tasks of a community of practice is to establish this common baseline and standardize what is well understood so that people can focus their creative energies on the more advanced issues" (p. 11). In this way, our shared understandings allowed us to advocate for continued attention to adolescent literacy at the district level. This became particularly important as we engaged more frequently with district-level policy and needed to "focus [our] creative energies" on finding ways to challenge the status quo.

\section{From shared discourse to action}

The Literacy Coach Collaborative provided a safe, fertile space where the four coaches were able to develop an authentic community of practice and where we could engage with possibilities and challenges of our coaching roles. Opportunities to co-construct coaching resources and tools, as well as to talk through challenges we faced, allowed us to develop and articulate shared beliefs about our work, beliefs that were grounded in critical theories about literacy instruction. However, in order to enact those beliefs, we needed to publicly advocate for change, both at the school and district levels. 


\section{Critically oriented leadership}

Critically oriented leaders are driven by social justice and equity goals, and they explicitly work to question and dismantle structures that stand in the way of these goals. They recognize that existing inequities are the direct, though often tacit and hidden, results of historical constructions of schooling and of the structures that guide school practices (Capper, 1998; Sirotnik \& Oakes, 1986). Capper (1998) offered a list of questions that leaders might pose if they are operating from a critically oriented perspective. When encountering a proposed change initiative, for example, they would pose questions such as: To what end is this reform being enacted? and "Who is benefitting from the situation? Whose interests are (and are not) being served by the situation? Whose knowledge/point of view is privileged?" (Capper, 1998, p. 358).

Though none of the coaches formally identified themselves as a critically oriented leader at the time, we recognized that existing programs and policies were not sufficient to support the students who were struggling within our district, and we explicitly linked these conversations with issues of race, culture, socioeconomic status and power. During one of our interviews, Carol expressed her frustration after attending a LCSD meeting about a proposed change within the district. She said, "I went for a walk [after a district meeting], and I was thinking, where are our kids of color? And our poor kids?" She articulated one of our shared beliefs: The needs of our historically marginalized students had to be articulated and prioritized. From her perspective, their needs were absent from a district-level conversation about reform that she had just attended.

Critically oriented educators can work both within the existing systems and "within the margins" (Lewison, Leland \& Harste, 2008, p. xxii) to promote equity and social justice ends, even within systems like the Lake City School District that are increasingly characterized by top-down mandates and a desire for consistency and fidelity. In Figure 1 below, I present a framework for coaches who are interested in working towards critical change within their districts.

This framework presents six approaches that the LCSD high school coaches employed in order to push for change within our schools and within the broader district context. These approaches are nonlinear and recursive, and they can occur simultaneously. This is reflected in the cyclical nature of the figure. For example, one way of advocating for increased attention to adolescent 
literacy is to recommend that available funds be used to purchase differentiated content-area texts.

As is indicated on the diagram below, these approaches also pose different levels of risk to the coaches who engage them in their daily work. For example, embedding critical literacy principles into a public document that a coach develops with like-minded colleagues is a much more discreet disruption of the status quo than is publicly questioning policies in the presence of district staff and administrators.

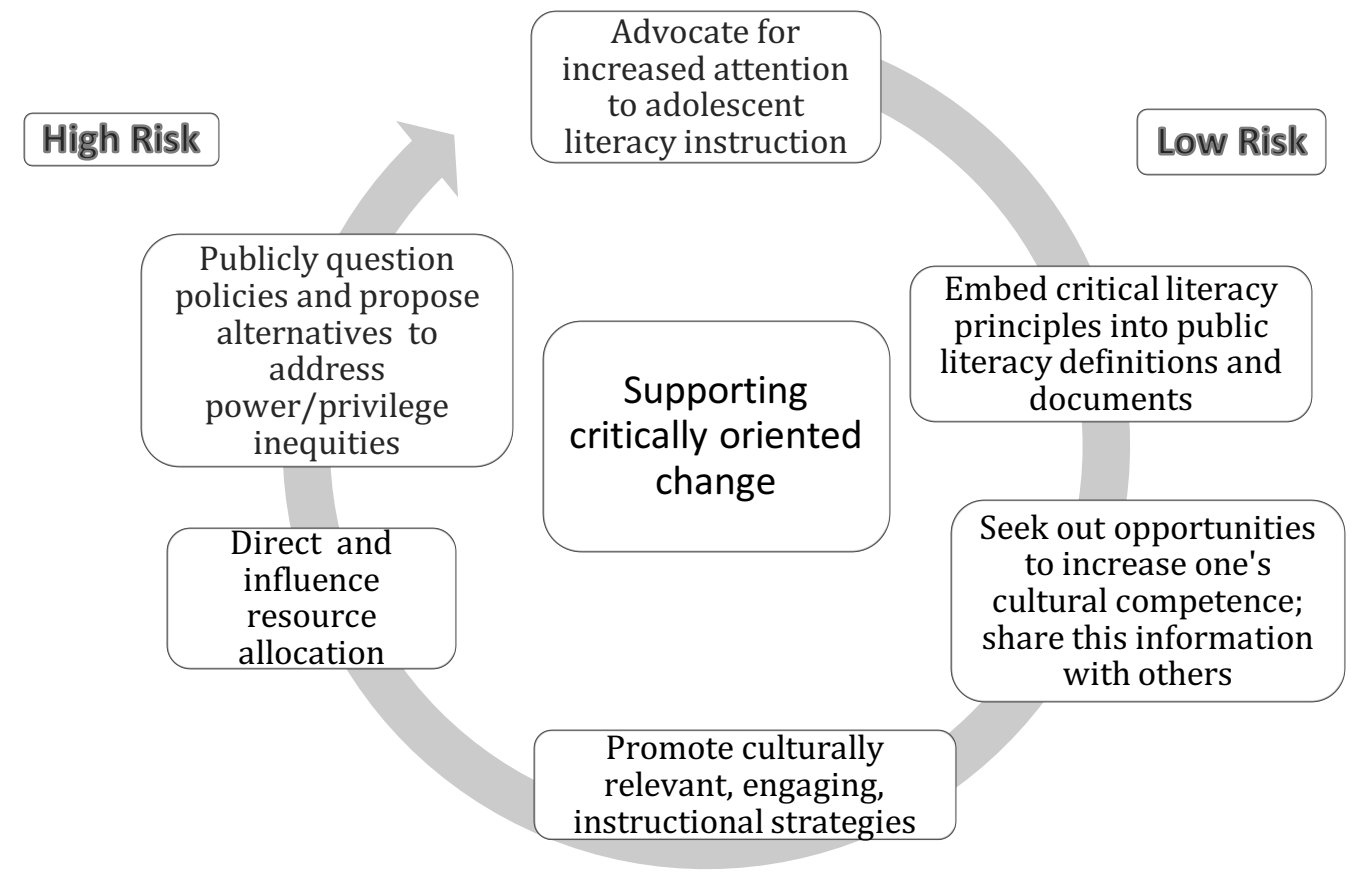

Figure 1. Critically oriented approaches to coaching role actions taken by the LSCD literacy coaches

\section{Conclusions \& Implications}

Unlike many coaches who are hired into their positions to support and enact particular policies or curricula such as Reading First (Deussen et al, 2007; Affinito, 2011), the LCSD coaches were hired to improve literacy on a broader scale. This, along with the structure of the Literacy Coach Collaborative, afforded us the opportunity to propose, negotiate and develop shared beliefs about our work. Ultimately, as we advocated for increased attention to adolescent literacy in our district, we tried to create critical spaces within the schools. The spaces valued multiple ways of knowing and encouraged the 
integration of diverse voices into the curriculum (Lewison, Leland \& Harste, 2008), recognized that race and class needed to be better understood and celebrated (Ladson-Billings, 2009), and advocated that resources be directed toward supporting the needs of our students who had been marginalized.

We encountered many obstacles along the way, and we were not always successful in our efforts. However, we knew that our collective voice, driven by our shared discourse, elevated these issues at both the school and district levels. Bean \& Carrol (2006) shared, "Coaches with whom we have worked indicate that the best form of professional development for them has been the opportunity to talk with other coaches" (p. 150). Building upon my own experiences in LCSD, I recognize the importance of giving coaches an opportunity to explore, together, the possibilities and challenges of their work. The framework for critically oriented coaching presented here can be used to initiate that conversation. As instructional coaching continues to expand, both within the United States and internationally, those who train and support coaches can create spaces for reflection, spaces that can help them answer the question, "To what end am I coaching?"

\section{References}

Affinito, S. (2011). Literacy Coaching: Negotiating Roles and Realities. Dissertation completed at University of Albany, State University of New York. UMI Number: 3489660. Retrieved from Proquest on February 9, 2012.

Aguilar, E. (2013). The Art of Coaching: Effective Strategies for School Transformation. San Francisco, CA: Wiley.

Apple, M. (2000). Official Knowledge: Democratic Education in a Conservative Age. New York, NY: Routledge.

Apple, M. (2004). Ideology and Curriculum. New York, NY: Routledge.

Apple, M. (2018). The Struggle for Democracy in Education: Lessons from Social Realities. New York, NY: Routledge.

Bakhtin, M.M. (1981). The Dialogic Imagination: Four Essays. Michael Holquist (Ed.). Trans. C. Emerson and M. Holquist. Austin, TX: University of Texas Press.

Bean, R. \& Carroll, K.E. (2006). The literacy coach as catalyst for change. In C. Cummins (Ed.), Understanding and implementing Reading First initiatives: The changing role of administrators. Newark, DE: International Reading Association. 
Blamey, K.L., Meyer, C.K. \& Walpole, S. (2008). Middle and high school literacy coaches: A national survey. Journal of Adolescent and Adult Literacy, 52(4), 310-323.

Capper, C. (1998). Critically oriented and postmodern perspectives: Sorting out the differences and applications for practice. Educational Administration Quarterly, 34(3), 354-379.

Carnegie Council for the Advancement of Adolescent Literacy. (2010). Time to Act: An Agenda for Advancing Adolescent Literacy for College and Career Success. New York, NY: Carnegie Corporation.

Cochran-Smith, M. \& Lytle, S. (1993). Inside/Outside: Teacher Research and Knowledge. New York, NY: Teachers College Press.

Compton-Lilly, C. (2004). Confronting Racism, Poverty, and Power: Classroom Strategies to Change the World. Portsmouth, NH: Heinemann.

Costa, A.L. \& Garmston, R.J. (2016). Cognitive Coaching: A Foundation for Renaissance Schools. Foxboro, MA: Christopher-Gordon.

Deussen, T., Coskie, T., Robinson, L. \& Autio, E. (2007). "Coach" can mean many things: Five categories of literacy coaches in Reading First. Issues \& Answers Report, REL, 5.

Fairclough, N. (1989). Language and Power. Essex, UK: Longman Group.

Freire, P. (2000). Pedagogy of the Oppressed: $30^{\text {th }}$ Anniversary Edition. New York, NY: Continuum International Publishing Group, Inc.

Fullan, M. (2011). Coaches as System Leaders. Educational Leadership, 69(2), 50-53.

Gee, J.P. (2011). An Introduction to Discourse Analysis: Theory and Method, $3^{\text {rd }} E d$. New York, NY: Routledge.

International Reading Association [IRA]. (2006). Standards for Middle and High School Literacy Coaches. Newark, DE: Author.

Janks, H. (2010). Literacy and Power. New York, NY: Routledge.

Ladson-Billings, G. (2009) The Dreamkeepers: Successful Teachers of African American Children. San Francisco, CA: Josey Bass.

Lewison, M., Leland, C. \& Harste, J. C. (2008). Creating Critical Classrooms: K-8 Reading and Writing with an Edge. New York, NY: Taylor \& Francis Group, LLC.

Morgan, W. (1997). Critical Literacy in the Classroom: The Art of the Possible. New York, NY: Routledge.

Morrell, E. (2008). Critical Literacy and Urban Youth: Pedagogies of Access, Dissent and Liberation. New York, NY: Taylor \& Francis. 
Mraz, M., Algozzine, B. \& Watson, P. (2008). Perceptions and Expectations of Roles and Responsibilities of Literacy Coaching. Literacy Research and Instruction, 47, 141-157.

Neufeld, B. \& Roper, D. (2003). Coaching: A strategy for developing instructional capacity-promises and practicalities. Report prepared for the Aspen Institute on Education and the Annenberg Institute for School Report.

Rogers, R. (2014). Coaching Literacy Teachers as They Design Critical Literacy Practices. Reading \& Writing Quarterly, 30, 241-261.

Saldaña, J. (2009). The Coding Manual for Qualitative Researchers. Thousand Oaks, CA: Sage Publications.

Sirotnik, K. \& Oakes, J. (1998). Critical Inquiry for School Renewal: Liberating Theory and Practice. In Authors (Eds) Critical Perspectives on the Organization and Improvement of Schools (pp. 3-93). Boston, MA: Kluwer-Nijhoff Publishing.

Sturtevant, E. (2003). The Literacy Coach: A key to improving teaching and learning in secondary schools. Alliance for Excellent Education.

Sweeney, D. (2011). Student-Centered Coaching: A Guide for K-8 Coaches and Principals. Thousand Oaks, CA: Corwin.

Vasquez, V. (2001). Constructing a Critical Curriculum with Young Children. In Comber B. and Simpson, A. (Eds.), Negotiating Critical Literacies in Classrooms (pp. 55-68). Mahwah, NJ: Lawrence Erlbaum Associates, Inc.

Weick, K. E. (2001). Making sense of the organization. Oxford: Blackwell.

Wenger, E., McDermott, R.A., Snyder, W. (2002). Cultivating Communities of Practice: A guide to managing knowledge. Boston, MA: Harvard Business School Press.

Zeni, J. (Ed.) (2001). Ethical Issues in Practitioner Research. New York, NY: Teachers College Press.

\section{Acknowledgements}

Many thanks to my wonderful coaching colleagues who agreed to participate in this study. I would also like to express gratitude to Julian Humphreys and to the anonymous reviewers who provided critical, actionable feedback. 


\section{Author Contact}

Questions about this paper can be directed to Laura M. Lang, in the Educational Leadership \& Policy Analysis Department at the University of Wisconsin-Madison: 1lang2@wisc.edu. 